\section{Special Investment Support Under the Agricultural Reorganisation Programme 1995-2000}

\author{
Lajos Juhász \\ University of Western Hungary, School of Economics, \\ Institute of Applied Economics, Sopron
}

\section{SUMMARY}

Since the political changes in Hungary, agricultural businesses have worked in a declining economic environment and hectic market situation, with a widening price gap between agricultural and industrial products and low profitability. A declining export comes then by no surprise. The sector has not been able to even benefit from export opportunities provided in the European Agreement. The area least benefiting from quotas is animal products (beef, mutton, lamb, slaughtered chicken, cheese, egg). The ministry of agriculture was lagging behind in responding to these problems, and it was as late as in 1995 when it launched a reorganisation programme for export stocks fund build-up (5).

The author has conducted empirical studies on agricultural enterprises in Csongrád county to see what results the special investment support delivered under the reorganisation programme produced. The fundamental aim of the reorganisation programme for export stocks fund build-up was to boost exportable Hungarian animal product stocks in a bid for businesses to better benefit from the preferential quotas set by the European Agreement. The author examined how the special investment support scheme succeeded in its aims, whether livestock grew considerably in its wake, whether farmers were able to attain exportable quality and what development funds enterprises were able to raise.

\section{OBJECTIVES OF THE PROGRAMME, AMOUNT OF SUPPORT}

The overall objective of the application scheme was to fill stock breeding farm vacancies closed after the sweeping changes with livestock as well as to create better conditions for breeding quality livestock for slaughter and producing high quality animal products and, eventually, improve the competitiveness of the agrarian sector both on internal and foreign markets. Under the scheme, stock breeders had the opportunity to apply for support for export stocks fund build-up, to finance farm vacancy purchase and upgrading (for cattle, hogs, sheep and poultry), livestock (cattle, hogs and sheep) purchase for filling vacancies and create funds to respond to an increasing demand for durable current asset procurement in the wake of putting the farm back to use. Support line for livestock purchase and farm vacancy fill-up as well as durable current asset procurement is shown in Table 1.

Support line for livestock purchase, farm vacancy fill-up and durable current asset procurement

\begin{tabular}{|l|r|r|r|r|c|}
\hline \multirow{2}{*}{ Support } & \multicolumn{4}{|c|}{ Limit } & \multirow{2}{*}{ Notes } \\
\cline { 2 - 6 } & $\begin{array}{c}\text { first-gravid heifer } \\
\text { Fts/animal }\end{array}$ & $\begin{array}{c}\text { first-gravid sow } \\
\text { Fts/animal }\end{array}$ & $\begin{array}{c}\text { breeder ewe } \\
\text { Fts/animal }\end{array}$ & $\begin{array}{c}\text { poultry } \\
\text { Fts/m2 }\end{array}$ & $\begin{array}{c}\text { one-time, non- } \\
\text { refundable, for } \\
\text { improvement }\end{array}$ \\
\hline $\begin{array}{l}\text { Livestock purchase } \\
\text { and vacancy fill-up }\end{array}$ & 35,000 & 10,000 & 3,500 & & $\begin{array}{c}\text { one-time, non- } \\
\text { refundable, for } \\
\text { improvement }\end{array}$ \\
\hline $\begin{array}{l}\text { Durable current asset } \\
\text { procurement }\end{array}$ & 10,000 & 9,000 & 3,000 & 1,000 & \\
\hline
\end{tabular}

Source: Relevant government decree, 1995 (5)

Support for both livestock purchase and vacancy fill-up and current asset procurement was one-time, non-refundable development support. It was obvious soon after announcing the application scheme that on the one hand, forms of support were not well defined, enabling not only businesses with development potentials to receive support but with a poor control, channelling aid to a large number of businesses risking some of the money would be swallowed up by units not using it efficiently, on the other hand, it was possible for farmers to get the announced support amounts after a successful application and before completing the investment, where follow-up control of whether businesses used investment support for designated purposed came late.

\section{MATERIAL AND METHOD}

Empirical studies of the programme were conducted in Csongrád county. Here, 132 agricultural enterprises applied for and were granted support, out of which 38 was picked, for time and financial limitations. To collect and evaluate information, a form of questions grouped under four headings was compiled. Data collected between 1996-2000 were put in tables and analysed with the help of charts. Then, model calculations were done to reveal the economic impact, direct and indirect, of the reorganisation scheme.

It is known from literature that the number of cost items to be considered in economic and business 
management terms exceeds that appearing in accounting, i.e. the amount of economic resources enterprises invest or, 'sacrifice', to secure the limited funds for operation should be examined (Kopányi, 1996).

Therefore, in economic calculations, it is wise to take account of normal profit, i.e. opportunity cost of equity as a factor of profitability (Illés, 1997). The implicit costs of an enterprise run on own funds and with own equipment that cannot be recorded in the books should therefore not be neglected nor should one forget that the enterprise must make a profit larger than the opportunity cost of equity to secure a continuous maintenance of permanently fixed assets in lockstep with technical development and continuous innovation in production.

As a key point of reference, a normative requirement (normative viewpoint) was identified in the empirical studies, which was taken equal to the return of reference on long-term government securities. Theoretically, this is risk-free return, the lowest locked-up capital can yield in a standard market environment. An other key point was the rate of inflation, taken into account in determining the discounting factor in the calculation of present value. After capitalising investments, the enterprise generates returns with fixed assets (machinery, buildings e.t.c.) in the course of the production process. Returns are comprised of depreciation expense and achieved income. Depreciation is aptly included in return because, although boosting production costs, the part of capital thus accounted is 'released' and the enterprise can make use of it as internal resource (Pfau, 1998). The aggregate of the two returns is the so-called capital resources from operation, a category extensively applied by foreign researchers in cost-effectiveness studies and in the calculation of certain financial indicators (McMahon, 1985).

Three factors were evaluated in examining the cost-effectiveness of agricultural investment, one being the time of return, which was estimated by dividing the invested amount by the aggregate discounted value of depreciation charge and income up to the first return on capital. The turnover of invested capital was calculated so that the discounted total of income and depreciation expense over the asset's useful life was divided by the invested amount (Pfau, 1998).

Economic profit was determined as capital resources from discounted operations less discounted capital demand, i.e. equity's opportunity cost.

\section{IMPLEMENTING THE REORGANISATION PROGRAMME IN CSONGRÁD COUNTY}

\subsection{An overview}

The reorganisation programme for export stocks fund build-up launched in 1995 imposed a five-year obligation of stock breeding on farmers after farm vacancies were filled up ( $80 \%$ of vacancies had to be filled within a year). This obligation was counted with in the course of the empirical studies conducted in Csongrád county between 1996-2000.

In respect of geographical distribution of accepted applications, $67 \%$ of applications accounting for almost $90 \%$ of the total amount invested in the county - came primarily from around the town of Szentes and the HódmezövásárhelySzeged-Makó region. These are also the areas with the longest-established traditions in husbandry where large stock breeding farms were concentrated before the economic-political changes, part of which closed down when the turn came. Even today, a few of the successors of large farms where livestock was retained are leading enterprises (e.g. Hódmezőgazda Rt., Hungerit Rt., Gorzsai Mezőgazdasági Rt.).

Apart from support for livestock and durable current asset procurement, the scheme also offered interest subsidy possibilities to farmers after they had drawn credits from financial institutions for livestock and breeding farm purchase and farm upgrading. Interest subsidy was meant to alleviate the burden of debt service on credits. Farmers were offered three types of interest subsidy on development credits drawn for breeding farm purchase and upgrading (Table 2).

Types of interest subsidy

\begin{tabular}{|c|c|c|c|c|c|c|c|}
\hline \multirow{2}{*}{ Type of subsidy } & \multicolumn{7}{|c|}{ Years } \\
\hline & 1 & 2 & 3 & 4 & 5 & 6 & 7 \\
\hline type I & 100.0 & 100.0 & 80.0 & 60.0 & 40.0 & 20.0 & 0 \\
\hline type II & 100.0 & 100.0 & 50.0 & 50.0 & 50.0 & 50.0 & 50.0 \\
\hline type III & 70.0 & 70.0 & 70.0 & 70.0 & 70.0 & 70.0 & 70.0 \\
\hline
\end{tabular}

Source: Relevant government decree, 1995 (5)

If the farmer drew credit from financial institutions for livestock purchase, there was a possibility for them to receive interest subsidy for $70 \%$ of the interest in respect of up to $40 \%$ of the purchase price, for a maximum of 7 years.

A down side to the support-for-application system was that farmers had to make the large-scale investment of purchasing and upgrading stock breeding farms without direct support and could only receive indirect support (interest subsidy) if they deployed outside funds to realise the investment. An other general condition of support was filling up vacancies with livestock of high genetic quality, capable of export stocks fund build-up and ensuring high-quality products. Obviously, the set of conditions for application was not geared to the 
targeted use of support. With no large stock breeding farms, livestock of high genetic value mostly fragmented and deteriorated, also, purchasing and breeding such valuable livestock requires special knowledge, missing with most farmers.

It was clear shortly after the announcement of the reorganisation programme for export stocks fund build-up that it failed to produce the hoped-for results, the support line was not efficiently allocated, there was no improvement in the genetic value of emerging livestock, nor were farmers able to produce goods of exportable quality.

The leadership of the agrarian sector perceived that the scheme missed targets and in 1999, the Ministry of Agriculture and Development issued a decree (6) to change application requirements whereby the originally five-year stock breeding obligation was reduced to three years in respect of cattle, hog and sheep dam and the obligation of poultry keeping was immediately cancelled when the decree took effect.

The lack of communication between sector management and banks is revealed by the discrepancy that the livestock breeding obligation of farmers that had drawn bank credit for investment project financing was ongoing, also, they had to repay the principal and interests according to the existing schedule which, the system of support not tailored to needs, plunged a number of enterprises, primarily family-run businesses, to serious indebtedness while the agrarian administration failed to take measures to alleviate the problem.

The overwhelming majority of businesses participating in the reorganisation programme for export stocks fund build-up were family-run enterprises, with some limited partnerships, private and public limited companies or co-operatives (Table 3).

Distribution of support delivered for farm upgrading and renovation as well as livestock purchase and durable current asset procurement under the reorganisation programme for export stocks fund build-up County of Csongrád, 1995

\begin{tabular}{|l|r|r|r|r|r|r|}
\hline \multirow{2}{*}{\multicolumn{1}{c}{ Form of business }} & \multirow{2}{*}{ No. of applications } & \multicolumn{1}{c|}{ A } & \multicolumn{2}{c|}{ B } & \multicolumn{2}{c|}{ C } \\
\cline { 3 - 6 } & & \multicolumn{4}{|c|}{ in thousand HUF } \\
\hline family-run enterprise & 105 & $135,108.0$ & $157,760.5$ & $1,286.7$ & $1,502.5$ \\
\hline limited partnership & 4 & $8,370.0$ & $8,365.0$ & $2,092.5$ & $2,091.3$ \\
\hline private limited company & 5 & $84,368.0$ & $57,647.0$ & $16,873.6$ & $11,529.4$ \\
\hline public limited company & 6 & $37,512.0$ & $20,298.0$ & $6,252.0$ & $3,383.0$ \\
\hline co-operative & 12 & $64,655.0$ & $40,099.5$ & $5,387.9$ & $3,341.6$ \\
\hline TOTAL & 132 & $330,013.0$ & $284,170.0$ & $2,500.0$ & $2,152.8$ \\
\hline
\end{tabular}

A: farm vacancy upgrading and renovation, total; B: livestock and durable current asset support, total; C: farm vacancy upgrading and renovation per company; D: livestock and durable current asset support per company

Source: own calculations based on figures of the Department of Agriculture of Csongrád county

Under the reorganisation programme, a total of approx. HUF 330 million was invested in livestock farm vacancies without direct support (no support was delivered for farm upgrading and renovation), companies drawing $60 \%$ and family enterprises, $40 \%$. Direct support, associated with purchasing livestock and durable current asset procurement, amounted to almost HUF 285 million, $60 \%$ of which went to family enterprises. In terms of investment financing and purchasing support per application, business associations obviously exceeded family-run businesses.

Enterprises based in Csongrád county invested almost $60 \%$ of the project budget in the upgrading of poultry units, $27 \%$ in hog farms and somewhat more than a mere $10 \%$ in unoccupied cattle farms (Table 4).

The majority of investment associated with poultry farming was made by family-run enterprises primarily because poultry farming is not capital intensive, family businesses are thinly capitalised, no special skills are required and, because support was not specifically targeted, a number of families were 'compelled' to set up an enterprise.
Table 4

Farm upgrading and renovation in Csongrád county 1995

\begin{tabular}{|l|r|r|}
\hline \multicolumn{1}{|c|}{ Animal } & $\begin{array}{r}\text { Invested amount } \\
\text { (thousand HUF) }\end{array}$ & Breakdown (\%) \\
\hline cattle & 36,538 & 11.1 \\
\hline hog & 88,162 & 26.7 \\
\hline sheep & 8,792 & 2.7 \\
\hline poultry (all kinds of) & 196,521 & 59.5 \\
\hline TOTAL & 330,013 & 100.0 \\
\hline
\end{tabular}

Source: own calculations based on figures of the Department of Agriculture of Csongrád county

Table 5 shows the breakdown by species of support for livestock purchase and durable current asset stock build-up.

Budgetary support for livestock purchase was about equal for cattle and hogs, $40 \%$ each, while the majority of support for durable current asset stock build-up went to hog farmers and $1 / 6$, to cattle farmers. The more intensive support of hog farming over cattle farming is due to a much less space demand of hogs compared to cattle, therefore hog breeding is more 'concentrated' and requires relatively extensive stocks of feed and porklings. 
Durable current asset support channelled to cattle farmers is insufficient even if farmers mostly grow bulk feed on their own land.

Reorganisation projects in cattle (93\%), hog (99\%) and sheep farming (87\%) were centralised in four regions: agricultural farmers around Szentes and Hódmezővásárhely got engaged in the breeding of all of the three species, while in the vicinity of Szeged, hog farming, around Balástya, sheep farming was opted for.

Breakdown by species of support for livestock purchase and durable current asset stock build-up County of Csongrád, 1995

\begin{tabular}{|l|r|r|r|r|r|r|}
\hline \multirow{4}{*}{ Species } & $\begin{array}{c}\text { Support for livestock purchase and } \\
\text { farm fill-up }\end{array}$ & $\begin{array}{c}\text { Support for durable current asset } \\
\text { procurement }\end{array}$ & \multicolumn{3}{c|}{ Total support } \\
\cline { 2 - 7 } & $\begin{array}{c}\text { amount } \\
\mathbf{1 , 0 0 0} \text { HUF }\end{array}$ & $\begin{array}{c}\text { breakdown } \\
\text { \% }\end{array}$ & $\begin{array}{c}\text { amount } \\
\mathbf{1 , 0 0 0} \text { HUF }\end{array}$ & $\begin{array}{c}\text { breakdown } \\
\text { \% }\end{array}$ & $\begin{array}{c}\text { amount } \\
\mathbf{1 , 0 0 0 ~ H U F}\end{array}$ & $\begin{array}{c}\text { breakdown } \\
\text { \% }\end{array}$ \\
\hline cattle & 19,845 & 38.0 & 5,670 & 16.5 & 25,515 & 29.5 \\
\hline hog & 20,090 & 38.5 & 18,081 & 52.7 & 38,171 & 44.1 \\
\hline sheep & 12,313 & 23.5 & 10,554 & 30.8 & 22,867 & 26.4 \\
\hline TOTAL & 52,248 & 100.0 & 34,305 & 100.0 & 86,553 & 100.0 \\
\hline
\end{tabular}

Source: Department of Agriculture of Csongrád county, 1995

Support given to poultry farmers was different inasmuch as it was delivered only to build up durable current asset stocks, as it had been determined in the programme. Support delivered in respect of four species: chicken, goose, turkey and duck, amounted to almost HUF 200 million (Table 6).

Breakdown of current asset support in poultry farming County of Csongrád, 1995

\begin{tabular}{|c|c|c|c|c|}
\hline \multirow[b]{2}{*}{ Poultry species } & \multicolumn{2}{|c|}{ Supported space } & \multicolumn{2}{|c|}{ (Durable) current asset support } \\
\hline & m2 & animal/m2 & $\begin{array}{c}\text { value } \\
\text { thousand HUF }\end{array}$ & $\begin{array}{c}\text { breakdown } \\
\% \\
\end{array}$ \\
\hline chicken & 105,217 & 12.6 & 105,217 & 53.2 \\
\hline goose & 61,140 & 4.0 & 61,140 & 31.0 \\
\hline turkey & 30,400 & 2.5 & 30,400 & 15.4 \\
\hline duck & 860 & 7.0 & 860 & 0.4 \\
\hline TOTAL & 197,617 & - & 197,617 & 100.0 \\
\hline
\end{tabular}

Source: own calculations based on figures of the Department of Agriculture of Csongrád county, 1995

The majority of the above amounts were granted to farmers engaged in chicken farming, overwhelmingly broiler breeding, while $30 \%$ went to those breeding goose (for meat or feather). 84\% of reorganisation projects in the four sectors of poultry farming were implemented by businesses based in the Szentes-Hódmezővásárhely-Szeged region.

\subsection{Empirical studies}

After giving an outline of how support was divided among the county's enterprises, empirical studies were conducted to reveal whether the programme succeeded in its aims and what impact it made.

To that end, a follow-up study of the production results of 38 agricultural enterprises (33 family-run enterprises, four co-operatives and a private limited company) was conducted over five years (19962000) after reorganisation investment. These included 12 businesses engaged in broiler breeding, 9 in meat goose farming, four in other poultry (turkey, duck) farming, four in dairy farming, three in cattle farming, three in hog breeding and three in sheep breeding.

The value of enterprises' capital engaged in production approached HUF 425 million, out of which farm upgrading and renovation accounted for 25 to $28 \%$. Upgrading was financed from internal as well as external sources. The average locked-up capital of family-run enterprises after completing the investment was HUF 6 million, that of companies, HUF 45 million. It was this locked-up capital that, besides reference return, fundamentally determined the demand for capital enterprises could use during the year (besides money for living).

In family enterprises, the capital demand per participant family member was primarily dependant upon the amount of capital employed in production on a long-term basis.

The regression curve shows (the logarithmic and correlative index of the correlation between the two variables showed a significantly strong interrelation) that capital demand per participant family member grew significantly in the case of locked-up capital up to HUF 5-6 million, while for larger values, the rate of capital demand increase was lower (Figure 1), 
extensive amounts of capital (HUF 20-30 million) locked up in production flattened the rise of the regression curve (because large family-run enterprises were compelled to employ more persons full-time - employees), on the other hand, farmers investing over HUF 5-6 million in production aimed at setting up independent family-run businesses and employ most of grown-up family members full-time.

Figure 1: Correlation between locked-up capital and capital demand per participant family member (family-run enterprises)

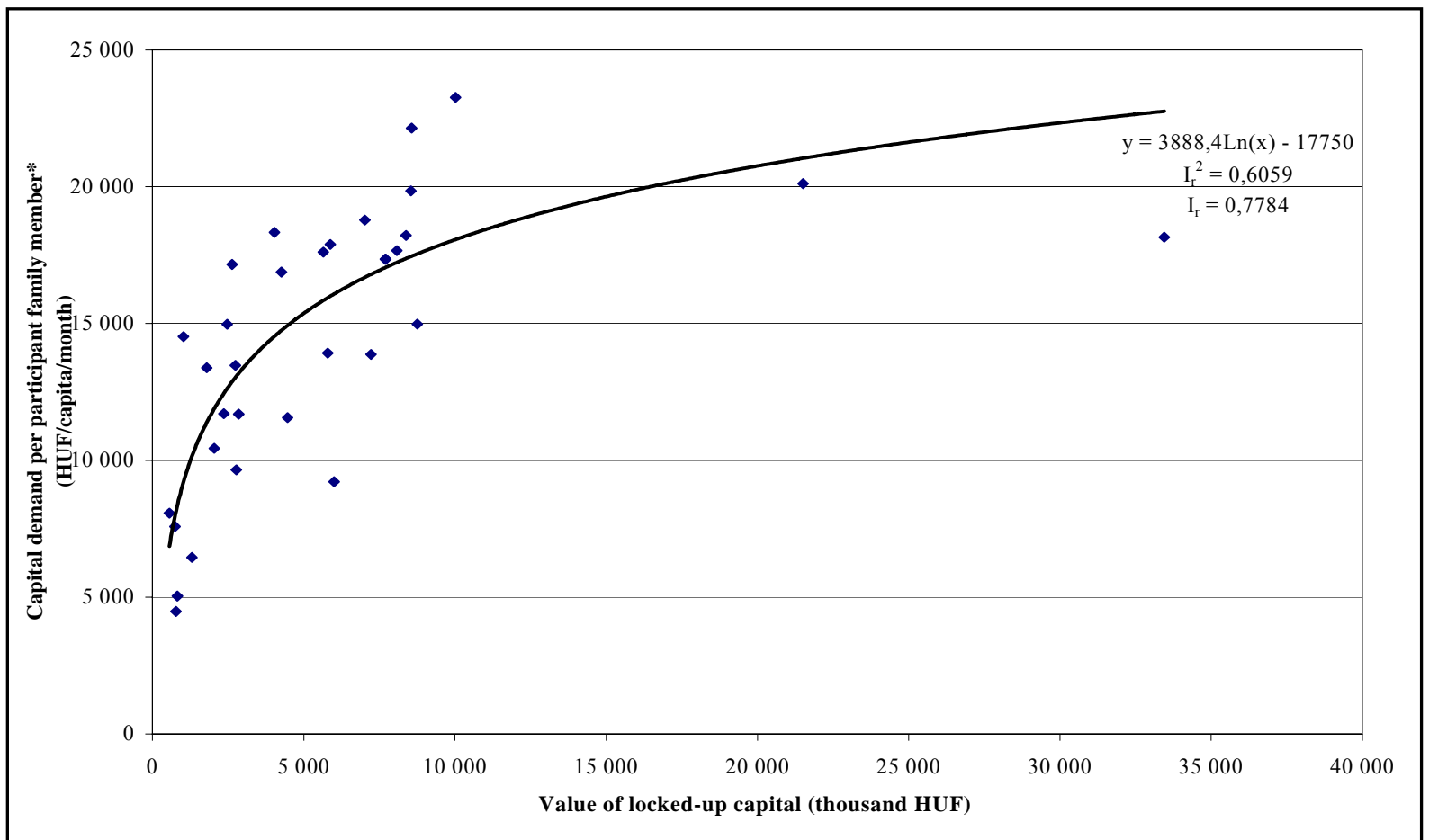

* at 1996 prices

Source: own calculations

After calculating the demand for locked-up capital, important for the determination of economic profit - see below, the amount and breakdown of various forms of support channelled under the programme was examined (Table 7 ).

Breakdown of support channelled under the reorganisation programme* County of Csongrád 1996-2000

\begin{tabular}{|c|c|c|c|c|c|c|c|c|c|}
\hline \multirow{3}{*}{ Activity } & \multicolumn{6}{|c|}{ Support } & & & \multirow{3}{*}{$\begin{array}{c}\text { No. of } \\
\text { enterprises }\end{array}$} \\
\hline & \multicolumn{2}{|c|}{ interest subsidy } & \multicolumn{2}{|c|}{ for livestock } & \multicolumn{2}{|c|}{$\begin{array}{c}\text { for durable current } \\
\text { asset procurement }\end{array}$} & \multicolumn{2}{|c|}{ Total support } & \\
\hline & 1,000 HUF & $\%$ & 1,000 HUF & $\%$ & 1,000 HUF & $\%$ & 1,000 HUF & $\%$ & \\
\hline $\begin{array}{l}\text { poultry } \\
\text { farming }\end{array}$ & 681.2 & 30.0 & - & - & $1,587.4$ & 70.0 & $2,268.6$ & 100.0 & 25 \\
\hline $\begin{array}{l}\text { milk } \\
\text { production }\end{array}$ & $3,163.2$ & 62.2 & $1,496.3$ & 29.4 & 427.5 & 8.4 & $5,087.0$ & 100.0 & 4 \\
\hline $\begin{array}{l}\text { beef cattle } \\
\text { production }\end{array}$ & 308.0 & 18.0 & $1,096.7$ & 63.8 & 313.3 & 18.2 & $1,718.0$ & 100.0 & 3 \\
\hline hog farming & 34.9 & 12.4 & 130.0 & 46.1 & 117.0 & 41.5 & 281.9 & 100.0 & 3 \\
\hline $\begin{array}{l}\text { mutton } \\
\text { production }\end{array}$ & 651.4 & 37.6 & 583.3 & 33.6 & 500.0 & 28.8 & $1,734.7$ & 100.0 & 3 \\
\hline $\begin{array}{l}\text { average } \\
\text { without } \\
\text { poultry }\end{array}$ & $1,202.8$ & 50.3 & 848.5 & 35.6 & 337.8 & 14.1 & $2,389.1$ & 100.0 & 13 \\
\hline
\end{tabular}


* projected to an average enterprise, at 1996 prices Source: own calculations 
Calculations revealed that poultry farming enterprises (broiler, duck, goose or turkey breeding) received $70 \%$ of support to finance durable current asset procurement and $30 \%$ as interest subsidy, i.e. due to a lesser demand for investment, businesses engaged in poultry farming drew relatively little credit to create funds. Enterprises working in other sectors of animal husbandry requiring more extensive investment drew larger amounts of credit (with dairies drawing the most), although, except for dairies, the share of interest subsidy was not conspicuously high due to a 'dampening' effect of livestock support.

Such interest subsidy, 50\% on the average, was of little help to farmers. On the one hand, product prime costs grew along with a growing interest burden because only a part of interest could be reclaimed as interest subsidy, on the other hand, principal repayment added to companies' expenses reduced profit after taxes.

A major objective of agricultural policy is to enhance the profitability of agricultural production through channelling support. On the basis of capital demand and amounts of support, model calculations were done in respect of the enterprises participating in the empirical study to survey the impact of support. The economic and 'adjusted' economic profit as well as the profit rate of agricultural businesses were calculated (Tables 8 and 9 ).

Table 8

Impact of support on the profitability of poultry farming enterprises under the reorganisation programme for export stocks fund build-up

\begin{tabular}{|c|c|c|c|c|c|c|c|c|}
\hline Investor & $\begin{array}{l}\text { Form of } \\
\text { business }\end{array}$ & $\begin{array}{c}\text { Locked-up } \\
\text { capital } \\
\text { thHUF }\end{array}$ & $\begin{array}{c}\text { Economic } \\
\text { profit* } \\
\text { thHUF/year }\end{array}$ & $\begin{array}{c}\text { Total } \\
\text { support } \\
\text { thHUF/year }\end{array}$ & $\begin{array}{c}\text { 'Adjusted' } \\
\text { economic } \\
\text { profit** } \\
\text { thHUF/year }\end{array}$ & $\begin{array}{c}\text { Economic } \\
\text { profit } \\
\text { rate*** } \\
\%\end{array}$ & $\begin{array}{c}\text { ‘Adjusted' } \\
\text { economic } \\
\text { profit } \\
\text { rate*** } \\
\% \\
\end{array}$ & $\begin{array}{c}\text { Increasing } \\
\text { impact on } \\
\text { economic } \\
\text { profit rate } \\
\% \\
\end{array}$ \\
\hline 1 & family-run & $2,040.0$ & -7.8 & 169.7 & 161.9 & -0.4 & 7.9 & +8.3 \\
\hline 2 & family-run & $21,510.0$ & 348.2 & $1,634.8$ & $1,983.0$ & 1.6 & 9.2 & +7.6 \\
\hline 4 & family-run & $2,746.0$ & -227.8 & 174.1 & -53.7 & -8.3 & -2.0 & +6.3 \\
\hline 5 & family-run & 560.0 & -40.9 & 16.6 & -24.3 & -7.3 & -4.3 & +3.0 \\
\hline 6 & family-run & 744.0 & -55.9 & 27.2 & -28.7 & -7.5 & -3.9 & +3.6 \\
\hline 7 & family-run & 820.0 & -72.6 & 44.9 & -27.7 & -8.9 & -3.4 & +5.5 \\
\hline 8 & family-run & 776.0 & -24.1 & 42.6 & 18.5 & -3.1 & 2.4 & +5.5 \\
\hline 11 & family-run & $1,304.0$ & -9.6 & 64.0 & 54.4 & -0.7 & 4.2 & +4.9 \\
\hline 12 & family-run & $2,358.0$ & -57.8 & 45.8 & -12.0 & -2.5 & -0.5 & +2.0 \\
\hline 14 & family-run & $2,775.0$ & -110.9 & 123.2 & -12.3 & -4.0 & -0.4 & +4.4 \\
\hline 15 & family-run & $5,651.0$ & -177.5 & 100.0 & -77.5 & -3.1 & -1.3 & +1.8 \\
\hline 18 & family-run & $33,455.0$ & $-1,049.5$ & $1,533.8$ & 484.3 & -3.1 & 1.4 & +4.5 \\
\hline 19 & family-run & $7,716.0$ & -104.0 & 330.4 & 226.4 & -1.3 & 2.9 & +4.2 \\
\hline 24 & family-run & $7,702.0$ & -113.7 & 276.0 & 162.3 & -1.5 & 2.1 & +3.6 \\
\hline 25 & family-run & $4,265.0$ & -200.7 & 190.0 & -10.7 & -4.7 & -0.3 & +4.4 \\
\hline 26 & family-run & $8,081.0$ & -398.2 & 240.2 & -158 & -5.0 & -2.0 & +3.0 \\
\hline 27 & family-run & $2,631.0$ & -130.6 & 80.0 & -50.6 & -4.9 & -1.9 & +3.0 \\
\hline 28 & family-run & $4,035.0$ & -260.6 & 120.0 & -140.6 & -6.4 & -3.4 & +3.0 \\
\hline 31 & family-run & $12,022.0$ & -453.3 & 490.0 & 36.7 & -3.8 & 0.3 & +4.1 \\
\hline 32 & family-run & $1,795.0$ & -77.5 & 96.0 & 18.5 & -4.3 & 1.0 & +5.3 \\
\hline 33 & family-run & $2,469.0$ & 32.3 & 110.6 & 142.9 & 1.3 & 5.8 & +4.5 \\
\hline 36 & family-run & $5,880.0$ & -68.4 & 309.8 & 241.4 & -1.2 & 4.1 & +5.3 \\
\hline 37 & family-run & $8,546.0$ & -145.2 & 401.2 & 256.0 & -1.7 & 3.0 & +4.7 \\
\hline Subtotal & - & $139,881.0$ & $-3,406.1$ & $6,620.9$ & $3,214.8$ & - & - & - \\
\hline Average & $(23)$ & $6,081.8$ & -148.1 & 287.9 & 139.8 & -2.4 & 2.3 & +4.7 \\
\hline 10 & co-operative & $19,280.0$ & $1,357.2$ & $1,444.2$ & 87.0 & -7.0 & 0,5 & +7.5 \\
\hline 17 & limited company & $39,229.0$ & $-2,213.9$ & $3,277.9$ & $1,064.0$ & -5.6 & 2.7 & +8.3 \\
\hline Subtotal & - & $58,509.0$ & $-3,571.1$ & $4,722.1$ & $1,151.0$ & - & - & \\
\hline Average & - & $29,254.5$ & $-1,785.6$ & $2,361.1$ & 575.5 & -6.1 & 2.0 & +8.1 \\
\hline Total & (25) & $198,390.0$ & $-6,977.2$ & $11,343.0$ & $4,365.8$ & - & - & 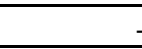 \\
\hline Average & - & $7,935.6$ & -279.1 & 453.7 & 174.6 & -3.5 & 2.2 & +5.7 \\
\hline
\end{tabular}

* discounted capital resource from operating activities after taxes less credits less capital demand

** total of economic profit and support

*** ratio of achieved profit to locked-up capital

Source: own calculations, 2000 
Impact of support on profitability under the reorganisation programme for export stocks fund build-up - cattle, hog and sheep breeding enterprises

\begin{tabular}{|c|c|c|c|c|c|c|c|c|}
\hline Investor & $\begin{array}{l}\text { Form of } \\
\text { business }\end{array}$ & $\begin{array}{c}\text { Value of } \\
\text { locked-up } \\
\text { capital } \\
1,000 \text { HUF }\end{array}$ & $\begin{array}{c}\text { Economic } \\
\text { profit* } \\
1,000 \\
\text { HUF/year }\end{array}$ & $\begin{array}{c}\text { Total } \\
\text { support } \\
\text { 1,000 } \\
\text { HUF/year }\end{array}$ & $\begin{array}{c}\text { ‘Adjusted' } \\
\text { economic } \\
\text { profit** } \\
1,000 \\
\text { HUF/year }\end{array}$ & $\begin{array}{c}\text { Economic } \\
\text { profit } \\
\text { rate }^{* * *} \\
\%\end{array}$ & $\begin{array}{c}\text { ‘Adjusted’ } \\
\text { economic } \\
\text { profit } \\
\text { rate*** } \\
\%\end{array}$ & $\begin{array}{c}\text { Augmented } \\
\text { economic } \\
\text { profit rate } \\
\text { by } \\
\%\end{array}$ \\
\hline \multicolumn{9}{|c|}{ Milk production } \\
\hline 9 & co-operative & $13,351.0$ & -335.8 & 507.0 & 171.2 & -2.5 & 1.3 & +3.8 \\
\hline 30 & co-operative & $62,642.0$ & -978.5 & $1,648.7$ & 670.2 & -1.5 & 1.1 & +2.6 \\
\hline 38 & co-operative & $90,298.0$ & $-2,279.0$ & $1,814.8$ & -464.2 & -2.5 & -0.5 & +2.0 \\
\hline 34 & family-run & $7,221.0$ & 94.6 & 99.0 & 193.6 & 1.3 & 2.7 & +1.4 \\
\hline Total & - & $173,512.0$ & $-3,498.7$ & $4,069.5$ & 570.8 & - & - & - \\
\hline Average & - & $43,378.0$ & -874.7 & $1,017.4$ & 142.7 & -2.0 & 0,3 & +2.3 \\
\hline \multicolumn{9}{|c|}{ Beef cattle production } \\
\hline 15 & family-run & $4,466.0$ & -313.0 & 329.4 & 16.4 & -7.0 & 0,4 & +7.4 \\
\hline 22 & family-run & $8,381.0$ & -349.2 & 417.8 & 68.6 & -4.2 & 0.8 & +5.0 \\
\hline 23 & family-run & $5,797.0$ & -336.9 & 238.8 & -53.1 & -5.8 & -0.9 & +4.9 \\
\hline Total & - & $18,644.0$ & -999.1 & $1,031.0$ & 31.9 & - & - & - \\
\hline Average & - & $6,214.7$ & -333.0 & 343.7 & 10.6 & -5.3 & 0.2 & +5.5 \\
\hline \multicolumn{9}{|c|}{ Hog farming } \\
\hline 13 & family-run & $7,023.0$ & -301.0 & 96.9 & -204.1 & -4.3 & -2.9 & +1.4 \\
\hline 29 & family-run & $2,849.0$ & 43.9 & 57.0 & 100.9 & 1.5 & 3.5 & +2.0 \\
\hline 35 & family-run & $1,028.0$ & -43.9 & 15.2 & -28.7 & -4.3 & -2.8 & +1.5 \\
\hline Total & - & $10,900.0$ & -213.2 & 169.1 & -131.9 & - & - & - \\
\hline Average & - & $3,633.3$ & -71.1 & 56.4 & -14.7 & -2.0 & -0.4 & +1.6 \\
\hline \multicolumn{9}{|c|}{ Mutton production } \\
\hline 3 & family-run & $8,758.0$ & $-1,099.8$ & 780.8 & -319.0 & 12.6 & -3.6 & +9.0 \\
\hline 20 & family-run & $6,008.0$ & -66.6 & 130.0 & 63.4 & -1.1 & 1.1 & +2.2 \\
\hline 21 & family-run & $8,569.0$ & -499.8 & 130.0 & -369.8 & -5.8 & -4.3 & +1.5 \\
\hline Total & - & $23,335.0$ & $-1,666.2$ & $1,040.8$ & -625.4 & - & - & - \\
\hline Average & - & $7,778.3$ & -555.4 & 346.9 & -208.5 & -7.1 & -2.7 & +4.4 \\
\hline
\end{tabular}

* discounted capital resource from operating activities after taxes less credits less capital demand

** total of economic profit and support

*** ratio of achieved profit to locked-up capital

Source: own calculations 2000

The impact of support was studied based on the assumption that the difference between economic and 'adjusted' economic profit rate was the result of budgetary support. Results show that support was insufficient to make a remarkable impact on profitability. Support delivered under the programme, fragmentary and insufficient, was not much of an effective aid nor did it enhance the position of most of businesses. Calculations also revealed (Table 10) that no visible profit was generated in any of the animal farming sectors in the wake of support granted under the programme nor did subsidy, augmenting profit by an average of $4.2 \%$, secure the raising of sufficient development funds. It merely helped enterprises achieve a zero balance.

With the above figures available, further model calculations were done (Table 11) to find out how big an economic profit that could be re-invested for innovation purposes and 'innovation bonus' should have been generated by funds made available to businesses by the programme between 1996-2000.
Model calculations showed that an average economic profit rate of almost $5 \%$ should have been achieved by producers to enable them to generate an average increase in owner's capital as might have been expected in the model. Empirical studies, on the other hand, revealed a realised economic profit rate of $1 \%$. In other words, not even with the subsidy were the analysed businesses able to do more than generate funds for merely covering the opportunity cost of locked-up capital.

Realising an average economic profit therefore would have required more budgetary support in the form of non-refundable 'investment base support' in a bid to generate development funds sufficient for agricultural production (Table 12).

Figures show that the management of the agricultural sector should have given almost a further HUF 110 million support in the form of investment base support to the 38 enterprises examined for the programme to have a perceivable favourable impact, an amount that compares to the funds from which producers participating in the empirical studies financed livestock farm upgrading and renovation. 
Impact of support received under the reorganisation programme for export stocks fund build-up on profitability (projected to an average business)

\begin{tabular}{|c|c|c|c|c|c|}
\hline Activity & $\begin{array}{l}\text { Economic profit } \\
1,000 \text { HUF / year }\end{array}$ & $\begin{array}{l}\text { 'Adjusted' } \\
\text { economic profit } \\
\text { 1,000 HUF / year }\end{array}$ & $\begin{array}{c}\text { Economic profit } \\
\text { rate } \\
\%\end{array}$ & $\begin{array}{c}\text { 'Adjusted' } \\
\text { economic profit } \\
\text { rate } \\
\%\end{array}$ & $\begin{array}{c}\text { Augmented profit } \\
\text { by } \\
\%\end{array}$ \\
\hline poultry farming & -279.1 & 174.6 & -3.5 & 2.2 & 5.7 \\
\hline milk production & -874.7 & 142.7 & -2.0 & 0.3 & 2.3 \\
\hline beef cattle production & -333.0 & 10.6 & -5.3 & 0.2 & 5.5 \\
\hline hog breeding & -71.1 & -14.7 & -2.0 & $-0,4$ & 1.6 \\
\hline mutton production & -555.4 & -208.5 & -7.1 & -2.7 & 4.4 \\
\hline Average & -351.4 & 110.8 & -3.2 & 1.0 & 4.2 \\
\hline
\end{tabular}

Source: own calculations 1996-2000

Expected return on investment completed under the reorganisation programme

\begin{tabular}{|c|c|c|c|c|c|c|c|c|c|}
\hline \multirow[b]{2}{*}{ Years } & \multicolumn{2}{|c|}{ Depreciation charge* } & \multirow[b]{2}{*}{$\begin{array}{c}\text { Profit } \\
\text { after } \\
\text { taxes** }\end{array}$} & \multirow{2}{*}{$\begin{array}{c}\text { Capital } \\
\text { resource from } \\
\text { operating } \\
\text { activities after } \\
\text { taxes }\end{array}$} & \multirow[b]{2}{*}{$\begin{array}{c}\text { Discounting } \\
\text { factor }^{* * *}\end{array}$} & \multirow[b]{2}{*}{$\begin{array}{c}\text { Discounted } \\
\text { value }\end{array}$} & \multirow[b]{2}{*}{$\begin{array}{c}\text { Capital } \\
\text { demand }^{* *}\end{array}$} & \multirow[b]{2}{*}{$\begin{array}{c}\text { Economic } \\
\text { profit }\end{array}$} & \multirow{2}{*}{$\begin{array}{l}\text { Average } \\
\text { expected } \\
\text { economic } \\
\text { profit rate }\end{array}$} \\
\hline & building & machines & & & & & & & \\
\hline 1996 & 4.68 & 3.19 & 21.5 & 29.37 & 0.8426 & 24.75 & 18.12 & 6.63 & \multirow{6}{*}{$\begin{array}{c}\text { economic } \\
\text { profit } \\
\text { rate }= \\
4.85 \%\end{array}$} \\
\hline 1997 & 4.68 & 3.19 & 17.3 & 25.17 & 0.7099 & 17.87 & 12.28 & 5.59 & \\
\hline 1998 & 4.68 & 3.19 & 14.9 & 22.77 & 0.5982 & 13.62 & 8.91 & 4.71 & \\
\hline 1999 & 4.68 & 3.19 & 11.7 & 19.57 & 0.5041 & 9.86 & 5.89 & 3.97 & \\
\hline 2000 & 4.68 & 3.19 & 8.0 & 15.87 & 0.4247 & 6.74 & 3.39 & 3.35 & \\
\hline Total & 23.40 & 15.95 & 73.4 & 112.75 & - & 72.84 & 48.59 & 24.25 & \\
\hline
\end{tabular}

* if locked-up capital is 100.0 (buildings accounting for 78 , machinery, for 22 ): depreciation of buildings $6 \%$, of machinery, $14.5 \%$

** taking into account the reference return on long term government securities

*** taking the rate of inflation into account

Source: own calculations 1996-2000 
Estimated expected support for investment under the reorganisation programme*

in 1,000 HUF

\begin{tabular}{|c|c|c|c|c|c|c|}
\hline $\mathbf{n}$ & Building & Machinery & $\begin{array}{c}\text { Locked-up } \\
\text { capital }\end{array}$ & Actual support & $\begin{array}{c}\text { 'Base amount of } \\
\text { investment } \\
\text { support }{ }^{\prime * *}\end{array}$ & Total support \\
\hline 1 & 532 & 324 & 2,040 & 848.7 & - & 848.7 \\
\hline 2 & 2,577 & 1,485 & 21,510 & $8,174.2$ & - & $8,174.2$ \\
\hline 3 & 3,193 & 1,155 & 8,758 & $3,904.2$ & $4,144.1$ & $8,048.3$ \\
\hline 4 & 1,309 & 700 & 2,746 & 870.4 & $1,067.8$ & $1,938.2$ \\
\hline 5 & 361 & - & 560 & 83.0 & 284.9 & 367.9 \\
\hline 6 & 452 & - & 744 & 136.0 & 359.9 & 495.9 \\
\hline 7 & 563 & - & 820 & 224.8 & 377.0 & 601.8 \\
\hline 8 & 367 & - & 776 & 213.0 & 133.1 & 346.1 \\
\hline 9 & 6,837 & 1,008 & 13,351 & $2,535.2$ & $3,028.9$ & $5,564.1$ \\
\hline 10 & 7,205 & 580 & 19,280 & $7,221.0$ & $5,176.0$ & 12,397 \\
\hline 11 & 673 & - & 1,304 & 320.0 & 107.7 & 427.7 \\
\hline 12 & 1,309 & - & 2,358 & 229.0 & 746.3 & 975.3 \\
\hline 13 & 2,800 & 367 & 7,023 & 484.7 & $3,064.2$ & $3,548.9$ \\
\hline 14 & 1,200 & 239 & 2,745 & 616.0 & 746.0 & $1,362.0$ \\
\hline 15 & 2,100 & - & 5.651 & 500.0 & $2,032.1$ & $2,532.1$ \\
\hline 16 & 920 & 474 & 4,466 & $1,647.0$ & $1,217.8$ & $2,864.8$ \\
\hline 17 & 18,153 & 10,698 & 39,229 & $16,389.7$ & $6,095.4$ & $22,486.1$ \\
\hline 18 & 16,073 & 5,732 & 33,455 & $7,669.1$ & $7,313.9$ & $14,983.0$ \\
\hline 19 & 3,881 & 825 & 7,716 & $1,652.2$ & $1,113.4$ & $2,765.6$ \\
\hline 20 & 631 & 400 & 6,008 & 650.0 & $1,431.5$ & $2,081.5$ \\
\hline 21 & 3,433 & 693 & 8,569 & 650.0 & $4,342.5$ & $4,992.5$ \\
\hline 22 & 2,502 & 400 & 8,381 & $2,089.0$ & $2,095.6$ & $4,184.6$ \\
\hline 23 & 1,893 & 390 & 5,797 & $1,419.0$ & $1,952.7$ & $3,371.7$ \\
\hline 24 & 3,881 & 625 & 7,702 & $1,380.0$ & $1,430.0$ & $2,810.0$ \\
\hline 25 & 1,510 & 150 & 4,265 & 950.0 & $1,294.5$ & $2,244.5$ \\
\hline 26 & 2,214 & 1,737 & 8,081 & $1,201.0$ & $3,141.8$ & $4,342.8$ \\
\hline 27 & 1,663 & - & 2,631 & 400.0 & $1,018.4$ & $1,418.4$ \\
\hline 28 & 2,578 & 850 & 4,035 & 600.0 & $1,877.0$ & $2,477.0$ \\
\hline 29 & 560 & 150 & 2,849 & 285.0 & 324.7 & 609.7 \\
\hline 30 & 25,581 & 4,686 & 62,642 & $8,243.4$ & $14,878.0$ & $23,121.4$ \\
\hline 31 & 3,405 & 930 & 12,022 & $2,450.0$ & $3,314.7$ & $5,764.7$ \\
\hline 32 & 365 & - & 1,795 & 480.0 & 429.7 & 909.7 \\
\hline 33 & 1,279 & 180 & 2,469 & 553.0 & 4.0 & 557.0 \\
\hline 34 & 1,874 & 580 & 7,221 & 495.0 & $1,133.4$ & $1,628.4$ \\
\hline 35 & 140 & 618 & 1,028 & 76.0 & 442.6 & 518.6 \\
\hline 36 & 1,100 & 150 & 5,880 & $1,549.0$ & 504.3 & $2,053.3$ \\
\hline 37 & 3,098 & 600 & 8,546 & $2,006.0$ & $1,206.9$ & $3,212.9$ \\
\hline 38 & 39,029 & 11,034 & 90,298 & $9,074.2$ & $28,597.4$ & $37,671.6$ \\
\hline Total & 167,241 & 47,760 & 424.781 & $88,268.8$ & $106,428.2$ & $194,697.0$ \\
\hline Average & 4,401 & $1,256.8$ & $11,178.4$ & $2,322.9$ & $2,800.7$ & $5,123.6$ \\
\hline
\end{tabular}

* calculating with a minimum expected profit rate $(4.85 \%)$

** no-consideration 'base support'

Source: own calculations 2000

\section{WHAT ECONOMIC IMPACT PROGRAMME HAS MADE}

The reorganisation programme for export stocks fund build-up contained contradicting elements as early as at the time of announcement. Application requirements were not geared to market requirements, the prerequisites for quality production were missing. The programme allowed the allocation of part of the given support for purposes other than specified while it failed to channel sufficient amounts to enterprises for them to be able to purchase and upgrade livestock breeding farms. Directly after the announcement of the programme, it could be predicted that it would fail to achieve the goals because the agricultural administration lacked the planning and strategy upon which such a system of support could be based. 
There was only a slight increase in livestock in Csongrád county in the wake of support coming under the programme: cattle stock grew by $2 \%$, while

hog and sheep stock, by approx. $0.5 \%$ each. Poultry stock, while showing a more perceivable increase, failed to produce goods of exportable quality. There came just a slight improvement in terms of the rate of employment, moreover, support, insufficient and channelled in an uncontrolled manner, changed enterprises' competitiveness for the worse instead of enhancing it. With a support programme announced to a large number of enterprises and budgetary support parcelled up, efficiency was low.

A major deficiency of the reorganisation programme, not carefully planned or the impact of it previously studied, was that it failed to grant nonrefundable base support for innovation. For agricultural enterprises, with low profitability and an ineffective capital gearing, credit drawing was on the whole detrimental, production costs and expenses grew, the 'beneficiary' was put into a disadvantageous position in terms of cost and competition, and income fell back.

Model calculations done as part of the empirical study of participating enterprises revealed $a$ declining trend because in economic terms, all of the species produced deficit. Even with the received subsidy, enterprises were only able to achieve a zero if not negative balance, which meant no innovation funds were generated at enterprises, moreover, enterprises operating with a zero balance could only finance operations from part of available funds or employing further resources from outside, which, in turn, further raised capital demand and debt service, leading to indebtedness or even bankruptcy for a number of units. In such a disorderly business and market environment, it is not surprising that farmers of Csongrád county were not able to produce exportable goods. Ample support, a reliable business environment as well a planned agricultural strategy for a few years ahead would have been much more beneficial.

\section{REFERENCES}

Illés M. (1997): Vezetői gazdaságtan. Kossuth Kiadó, Budapest Kopányi M. (1996): Mikroökonómia. Müszaki Kiadó, Budapest McMahon, G. P. (1985): How to Understand Financial Information? Business Information Review, 2. 15-21.

Pfau E. (1998): A mezőgazdasági vállalkozások termelési tényezői, erőforrásai. Egyetemi jegyzet, DE, Debrecen
Governmental regulation No. 187/1994 (XII.30.) of the Ministry of Agriculture on issues of granting support to the agricultural sector amended by Governmental regulations No. 14/1995 (II.10.), 57/1995 (V.17.) and 86/1995 (VII.14.)

Ministerial decree No. 8/1999 (I.20.) of the Minister of Agriculture and Development on the 1999 budgetary support of the agribusiness sector 